\title{
Fluid Shear Stress Induces Renal Epithelial Gene Expression through Polycystin-2-Dependent Trafficking of Extracellular Regulated Kinase
}

\author{
Daniel Flores $^{a} \quad$ Lorenzo Battini $^{a} \quad$ G. Luca Gusella ${ }^{a}$ Rajeev Rohatgi ${ }^{a-c}$ \\ Departments of a Medicine and ${ }^{b}$ Pediatrics, The Mount Sinai School of Medicine, and ${ }^{c}$ Department of Medicine, \\ The James J. Peters VA Medical Center, New York, N.Y., USA
}

\section{Key Words}

Extracellular regulated kinase $\cdot$ Fluid shear stress $\cdot \operatorname{IMCD} 3$ cells $\cdot$ Mitogen-activated protein kinase $\cdot$ Polycystin-2 • Renal epithelial gene expression

\begin{abstract}
Background: The cilium and cilial proteins have emerged as principal mechanosensors of renal epithelial cells responsible for translating mechanical forces into intracellular signals. Polycystin-2 (PC-2), a cilial protein, regulates flow/shearinduced changes in intracellular $\mathrm{Ca}^{2+}\left(\left[\mathrm{Ca}^{2+}\right]_{\mathrm{i}}\right)$ and recently has been implicated in the regulation of mitogen-activated protein (MAP) kinases. We hypothesize that fluid shear stress (FSS) activates PC-2 which regulates MAP kinase and, in turn, induces MAP kinase-dependent gene expression, specifically, monocyte chemoattractant protein-1 (MCP-1). Methods: To test this, PC-2 expression was constitutively reduced in a murine inner medullary collecting duct (IMCD3) cell line, and the expression of FSS-induced MCP-1 expression and MAP kinase signaling compared between the parental (PC-2-expressing) and PC-2-deficient IMCD3 cells. Results: FSS induces MAP kinase signaling and downstream MCP-1 mRNA expression in wild-type IMCD3 cells, while inhibitors of MAP kinase prevented the FSS-induced MCP-1 mRNA response. In contradistinction, FSS did not induce MCP-1 mRNA expres-
\end{abstract}

sion in PC-2-deficient cells, but did increase activation of the upstream MAP kinases. Wild-type cells exposed to FSS augmented the nuclear abundance of activated MAP kinase while PC-2-deficient cells did not. Conclusions: PC-2 regulates FSS-induced MAP kinase trafficking into the nucleus of CD cells.

Copyright $\odot 2010$ S. Karger AG, Basel

\section{Introduction}

It is well established that endothelial cells (ECs) respond to mechanical forces, such as stretch, hydrostatic pressure and fluid shear stress (FSS), with immediate transduction events, intermediate responses and longterm cellular adaptation [1-3]. Emerging evidence suggests that epithelial cells lining tubular structures, such as the nephron, also respond to variations in hydrodynamic forces with alterations in ion transport and signaling pathways $[4,5]$. The apical central cilium present on all renal epithelial cells, perhaps with the exclusion of intercalated cells [6], is believed to be the flow sensor which mediates FSS-induced increases in intracellular $\mathrm{Ca}^{2+}$ concentration $\left(\left[\mathrm{Ca}^{2+}\right]_{\mathrm{i}}\right)[7-9]$. Proteins localized to the cilium are believed to play an important role in FSSinduced signaling. In particular the polycystin-1 (PC-1)/

\section{KARGER}

(C) 2010 S. Karger AG, Basel

Fax +4161306 1234 E-Mail karger@karger.ch www.karger.com www.karger.com/nep
Rajeev Rohatgi, MD

One Gustave L. Levy Place, Box 1243

The Mount Sinai School of Medicine

New York, NY 10029 (USA)

Tel. +1 212241 7240, Fax +1 212426 1972, E-Mail rajeev.rohatgi@ mssm.edu 
polycystin-2 (gene name PKD2; protein name PC-2) protein complex, present in the cilium, is believed to be the mechanosenory complex leading to the FSS-induced $\left[\mathrm{Ca}^{2+}\right]_{\mathrm{i}}$ response, through extracellular $\mathrm{Ca}^{2+}$ entry and intracellular $\mathrm{Ca}^{2+}$ release [9]. Of note is that mutations of ciliary proteins are associated with dysregulated FSSmediated $\left[\mathrm{Ca}^{2+}\right]_{\mathrm{i}}$ response and the development of polycystic kidney disease (PKD) suggesting that an inability to properly sense biomechanical signals by tubular epithelia may contribute to the pathogenesis of cyst development [9-14]. For example, abrogation of fluid flow through the pronephros prevents normal tubular epithelial cell migration, implicating tubular fluid flow and its accompanying biomechanical forces as cues to tubular growth and development [15]. In addition, left-right axis asymmetry during development is regulated, in part, by PC-2 containing cilia exposed to apical fluid flow which induces asymmetric $\left[\mathrm{Ca}^{2+}\right]_{\mathrm{i}}$ signals along the left border of the node, illustrating the importance of fluid shear and appropriate cellular signaling during growth [16].

Many renal diseases are associated with increases in single nephron glomerular filtration rate (snGFR) with consequent alterations in tubular flow rate $[17,18]$. Diabetic nephropathy, the most common cause of chronic kidney disease, begins with hyperfiltration and intraglomerular hypertension [17]. Most structural kidney diseases associated with nephron loss follow a course characterized by compensatory increases of snGFR in 'normal' nephrons and tubular flow rate $[18,19]$. PKD, though not considered primarily a glomerular disease, is associated with abnormalities in water metabolism, such that the kidneys are unable to maximally conserve water [20]. This defect in water metabolism contributes to high urine flow rates and volumes observed in autosomal dominant PKD (ADPKD) [20-22] and autosomal recessive PKD (ARPKD) [20, 23]. Moreover, incremental increases in urinary flow rate, as measured by 24-hour urine volume collections, are associated with greater declines in renal function in patients with ADPKD or undifferentiated etiologies of chronic kidney disease suggesting altered urine flow rate may contribute to declines in renal function [24]. Thus, high urinary flow rates are common complications of kidney disease, but the impact of high tubular flow rates on maintenance of tubular epithelial integrity is unknown.

Basic studies investigating the downstream effects of FSS on renal epithelial biology are lacking. However, the effects of FSS on ECs have been extensively studied and can act as a model by which we can approach the analysis of the effects of FSS on renal epithelia. In particular, FSS induces phosphorylation (and activation) of the extracellular regulated kinase (ERK) and c-Jun N-terminal kinase (JNK) of the mitogen-activated protein (MAP) kinase family of signaling proteins in ECs $[25,26]$. This process, in turn, induces monocyte chemoattractant protein-1 (MCP-1) mRNA expression in ECs $[25,26]$. The precise endothelial biomechanosensor underlying this response remains elusive though several studies suggest that Gcoupled proteins and integrins are major contributors [27-29]. In renal epithelial cells, PC-2, a mechanosenor, has been implicated in regulating MAP kinase activation. Arnould et al. [30] have shown that overexpression of PC-2 induces JNK and p38 activation, and Grimm et al. [31] showed that hepatocyte growth factor (HGF) or epidermal growth factor (EGF)-induced PC-2 activation regulates trafficking of ERK into the nucleus. Based on these findings, we hypothesized that FSS activates PC-2 which regulates MAP kinase and, in turn, induces MAP kinasedependent gene expression, specifically, MCP-1.

\section{Materials and Methods}

\section{Generation of PC-2-Deficient Inner Medullary Collecting}

Duct (IMCD3) Cells

The lentiviral vector for the expression of short hairpin RNA specific for PKD2 was generated by annealing of the oligonucleotides siPKD/1674/S: $5^{\prime}$-gatcccgtatagctgctgtcatggtactaacagataccatgacagcagctatatttttcg- $3^{\prime}$ and siPKD2/1674/AS: $5^{\prime}$-aattcgaaaa atatagctgctgtcatggtatctgttagtaccatgacagcagctatacgg- $3^{\prime}$ and ligating them between the BAMHI and EcoRI sites of the VIRHD/P lentiviral vector [32]. The resulting VIRHD/P/siPKD2 lentivector and the control vector VIRHD/P/siLuc, which expresses a short hairpin RNA specific for the luciferase gene [32], were produced as described [33], and used at a multiplicity of infection of 20 to transduce IMCD3 cells. Polyclonal populations of stably transduced PC-2 knockdown and siLuc control IMCD3 cells were obtained following selection with $5 \mu \mathrm{g} / \mathrm{ml}$ puromycin in complete media for 5 days. To confirm PC-2 knockdown, a Western blot for PC-2 protein expression was performed on total protein lysate of parental untransduced IMCD3, VIRHD/P/siLuc-transduced, and VIRHD/P/siPKD2-transduced IMCD3 cells.

\section{Cell Culture}

Murine parental IMCD3 and PC-2-deficient IMCD3 cells were grown in DMEM/F12 (with $10 \%$ fetal bovine serum) on 25 $\times 75 \mathrm{~mm}$ glass slides and studied when they reached confluence between 3 and 7 days. We only used parental IMCD3 and PC-2deficient cells up to passage number 15 due to the risk of genetic drift.

Induction of Fluid Shear Stress

Cells grown on glass slides were placed in a laminar flow chamber (Glycotech, Gaithersburg, Md., USA), maintained at $37^{\circ} \mathrm{C}$ and subject to shear of $0.4 \mathrm{dyn} / \mathrm{cm}^{2}$ using phenol red-free, 
serum-free DMEM/F12 containing penicillin/streptomycin for varying durations. FSS was calculated based on Poiseulle's law; $\tau=\mu \gamma=6 \mu \mathrm{Q} / \mathrm{a}^{2} \mathrm{~b}$, where $\tau=$ wall stress $\left(\mathrm{dyn} / \mathrm{cm}^{2}\right), \gamma=$ shear rate (per second), $\mu=$ apparent viscosity of the fluid (media at $37^{\circ} \mathrm{C}=$ $0.76 \mathrm{cP}), \mathrm{a}=$ channel height $(\mathrm{cm} ; 0.0127 \mathrm{~cm}), \mathrm{b}=$ channel width $(\mathrm{cm} ; 1 \mathrm{~cm})$, and $\mathrm{Q}=$ volumetric rate $(\mathrm{ml} / \mathrm{s})$. Static control cells were exposed to the same solution and duration as sheared cells, but without exposure to FSS. Cells were then collected for total RNA or protein.

\section{Quantitative Real-Time PCR}

RNA was extracted from cells, as indicated, and cDNA synthesized using random primers [34]. Murine GAPDH was chosen as the internal positive reference control. qRT-PCR was performed as follows. In a 384-well plate, a $0.2-\mu \mathrm{l}$ cDNA sample was added plus $8 \mu$ l of a cocktail mix containing $0.05 \mu$ l Platinum Taq DNA Polymerase ${ }^{\circledR}, 1 \mu \mathrm{l}$ of $10 \times$ PCR buffer, $1.1 \mu$ l of $50 \mathrm{~mm}$ magnesium chloride, $0.1 \mu \mathrm{l}$ AmpErase ${ }^{\circledR}$ Uracil N-Glycosylase (UNG), $0.2 \mu \mathrm{l}$ Gene $\mathrm{Amp}^{\circledR}$ dNTPs with dUTP, $0.2 \mu \mathrm{l}$ passive reference ROX dye, $0.2 \mu \mathrm{l}(20 \mathrm{pM})$ forward and reverse primers, and $0.04 \mu \mathrm{l}$ Taqman $^{\text {TM }}$ probe. Taq DNA Polymerase ${ }^{\circledR}$ and ROX were purchased from Invitrogen (Carlsbad, Calif., USA) and AmpErase UNG, and dNTPs with dUTP from Applied Biosystems (Foster City, Calif., USA). Nuclease-free water was added for a total volume of $10 \mu \mathrm{l}$. Each plate was then covered with optical adhesive film and, after the initial steps of $50^{\circ} \mathrm{C} / 2 \mathrm{~min}$ and $95^{\circ} \mathrm{C} / 10 \mathrm{~min}$, 40 cycles of $95^{\circ} \mathrm{C} / 15 \mathrm{~s}$ (melt) and $60^{\circ} \mathrm{C} / 1 \mathrm{~min}$ (anneal/extend), detection was performed in an ABI Prism 7900HT using SDS 2.2.1, Sequence Detection System software.

\section{Isolation of Cytosolic and Nuclear Fractions for \\ Immunoblotting}

Cytosolic and nuclear subcellular fractions were isolated from static and sheared cells for Western blotting using Nuclear and Cytoplasmic Extraction Kit (Thermoscientific, Waltham, Mass. USA). In short, the cytoplasmic extraction reagent (CER) I, CERII, and nuclear extraction reagent solutions containing protease inhibitors were added sequentially, as described in the instructions, at a ratio of 1:0.055:0.5 to the cell pellet to isolate the subcellular fractions for Western blotting.

\section{Western Blotting}

Western blot analysis was performed as previously described [35]. Cellular protein lysates $(30 \mu \mathrm{g})$ were isolated as described above, resolved electrophoretically, and transferred to Immobilon filters (Millipore, Billerica, Mass., USA). Filters were blocked in 5\% non-fat dried milk and $0.05 \%$ Tween, and immunoblotted with an anti-phospho-antibody (see Reagents). After washing, blots were incubated with a horseradish peroxidase-conjugated secondary antibody (Sigma, St. Louis, Mo., USA) and bands visualized by the West Pico enhanced chemiluminescence kit (Pierce, Rockford, Ill., USA). After stripping the membrane and blocking, the blot was incubated with an anti-total-protein-specific antibody (Cell Signaling, Danvers, Mass., USA) and visualized using the same methods as the primary antibody. The phosphorylated protein was expressed as a ratio to the total amount of that protein present.

\section{Immunofluorescence}

Monolayers were fixed in $2.5 \%$ paraformaldehyde, permeabilized and blocked with $0.05 \%$ Triton X-100, $1 \%$ bovine serum al- bumin (BSA), and 10\% normal goat serum (NGS) in phosphatebuffered saline (PBS). Cells were incubated with a 1:200 dilution of a mouse monoclonal antibody directed against acetylated $\alpha$ tubulin overnight at $4^{\circ} \mathrm{C}$ and washed with PBS. A 1:500 dilution of Alexa Fluor ${ }^{\circledR}$-conjugated goat anti-mouse IgG (Invitrogen) prepared in a $1 \%$ BSA/1\% NGS/PBS solution was applied as a secondary antibody for $60 \mathrm{~min}$ at room temperature; thereafter, the cells were washed with PBS. Labeled cells were placed face down on a slide to which $15 \mu \mathrm{l}$ of Prolong Anti-Fade solution (Invitrogen) had been applied. Each monolayer was examined by confocal laser scanning microscopy (LSM-510 Confocal Microscope, Carl Zeiss Microimaging, Göttingen, Germany).

\section{Reagents}

Inhibitors. U0126, $10 \mu \mathrm{M}$ (Calbiochem, San Diego, Calif., USA); SP600125, $30 \mu \mathrm{M}$ [36] (Calbiochem) primers for qRT-PCR (Applied Biosciences): MCP-1 (Mm00441242_m1), transforming growth factor- $\beta_{1}$ (TGF- $\beta_{1} ; \mathrm{Mm} 00441724$ m1), tissue-plasminogen activator (t-PA; mM0047693_m1), and GAPDH (Mm99999915_g1).

Antibodies. Anti-polycystin-2 antibody (gift of S. Somlo); monoclonal anti-acetylated $\alpha$-tubulin (Abcam, Cambridge, Mass., USA), goat anti-mouse Alexa 488 (Invitrogen), rabbit polyclonal anti-phospho-ERK [1:1,000] (Cell Signaling), rabbit polyclonal anti-total-ERK $[1: 1,000]$ (Cell Signaling), rabbit anti-phospho-JNK [1:1,000] (Cell Signaling), anti-total JNK [1:1,000] (Cell Signaling), mouse monoclonal anti-glyceraldehyde-3-phosphate dehydrogenase (GAPDH) [1:4,000] (Santa Cruz Biotechnology), goat anti-rabbit conjugated to horseradish peroxidase $[1: 5,000]$ (Sigma).

\section{Results}

Because several studies have shown that PC-2 acts as (1) a flow-sensitive cation channel [9], (2) a mediator of MAP kinase signaling [30], and (3) a regulator of MAP kinase subcellular localization [31], we chose to test the hypothesis that FSS activates PC-2 which, in turn, regulates MAP kinase signaling by first generating a cell line deficient in PC-2. Next, we would compare flow-mediated signaling between PC-2-deficient cells and the parental wild-type controls. PC-2-deficient cells were generated by transfecting cells with lentivirus-based vector containing a short hairpin siRNA directed against murine PC-2 (fig. 1a). Control IMCD3 cells were transfected with a siRNA directed against luciferase. To assess PC-2 knockdown, PC-2 protein expression was determined by immunoblot on protein lysates of parental untransduced IMCD3, control VIRHD/P/siLuc transduced, and VIRHD/P/siPKD2 transduced IMCD3 cells (fig. 1b). Comparable expression of $\mathrm{PC}-2$ protein was detected in untransduced IMCD3 cells and control VIRHD/P/siLuc transduced, while IMCD3 cells transduced with the 


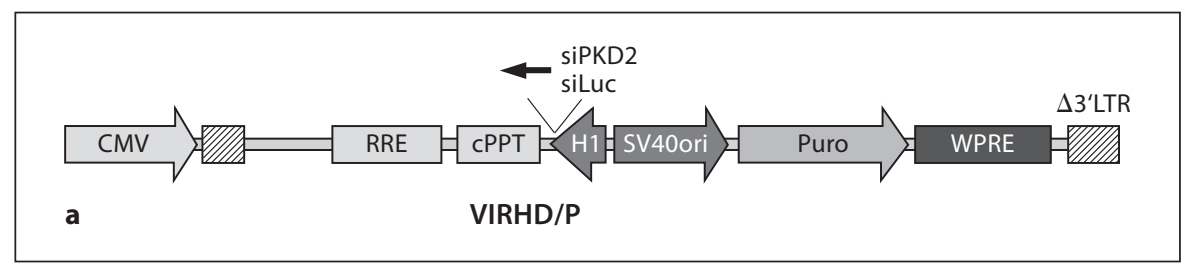

Fig. 1. Generation of PC-2-deficient murine IMCD3 cells. a A siRNA oligonucleotide directed against PKD2 (siPKD2) was ligated into a lentivirus vector. A control vector was generated with a siRNA directed against luciferase (siLuc). After transduction and selection, IMCD3 cells containing siPKD2 and siLuc lentivirus vector were isolated. b Western blot of untransduced, VIRHD/P/siLuc transduced, and VIRHD/ $\mathrm{P} /$ siPKD2 transduced IMCD3 cells demonstrate that the VIRHD/P/siPKD2 IMCD3 cells express $\sim 20 \%$ PC-2 protein compared to untransduced and control transduced cells.

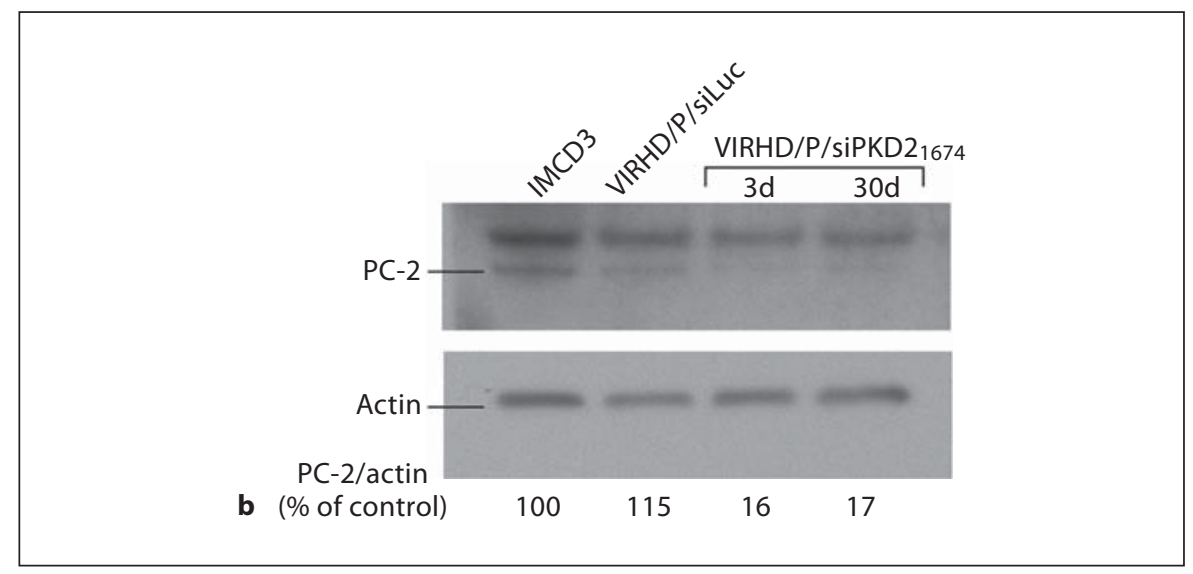

VIRHD/P/siPKD2 vector expressed $\sim 80 \%$ less PC-2 protein. A similar level of reduced PC-2 expression in the VIRHD/P/siPKD2 transduced cells was observed up to 30 days in culture and confirmed the stable knockdown (fig. 1b).

We next sought to test whether wild-type (PC-2-expressing) IMCD 3 cells respond to FSS by inducing MAP kinase-dependent gene expression, similar to the response seen in ECs. IMCD3 cells were exposed to $2 \mathrm{~h}$ of FSS at a shear of $0.4 \mathrm{dyn} / \mathrm{cm}^{2}$, a modeled physiologic shear for the mammalian distal nephron [37]. FSS significantly induced mRNA expression of MCP-1 compared to static controls; however, this same mechanical stimulus had no effect on t-PA and transforming growth factor- $\beta_{1}$ (TGF- $\beta_{1}$ ) mRNA expression (fig. 2 ) suggesting the FSS activates specific cellular signaling pathways leading to unique gene expression.

To test whether MCP-1 expression is regulated by ERK- and JNK-dependent pathways, as in ECs, IMCD3 cells were exposed to $0.4 \mathrm{dyn} / \mathrm{cm}^{2}$ of shear for $10,30,60$ and $120 \mathrm{~min}$ and the steady-state abundance of phosphorylated ERK (pERK) protein was compared between sheared and static cells. pERK expression was significantly greater in cells exposed to FSS from 10 to $120 \mathrm{~min}$ compared to static cells (fig. 3a, b). Next, JNK phosphorylation was measured in static cells, and cells exposed to FSS of $0.4 \mathrm{dyn} / \mathrm{cm}^{2}$ for $10-120 \mathrm{~min}$. Phosphorylation of

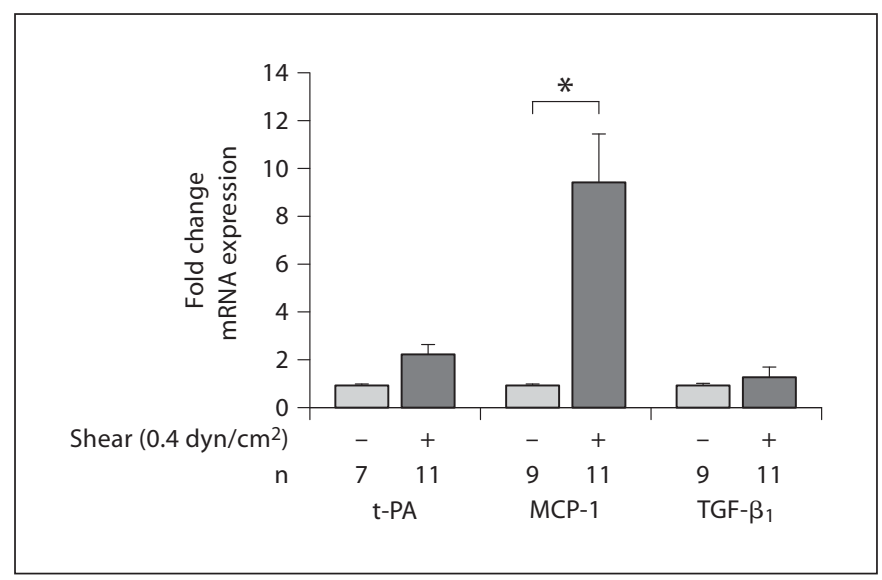

Fig. 2. MCP-1 mRNA expression in IMCD3 cells exposed to FSS. IMCD3 cells exposed to $0.4 \mathrm{dyn} / \mathrm{cm}^{2}$ of shear for $2 \mathrm{~h}$ were compared to static controls. FSS-induced MCP- $1\left({ }^{*} \mathrm{p}<0.05\right.$ compared to static) and did not affect TGF- $\beta_{1}$ and t-PA mRNA expression.

JNK was slightly increased at $30 \mathrm{~min}$, and robust at 60 and 120 min compared to static control cells (fig. 4a). Densitometric analyses of multiple Western blots for pJNK showed that pJNK expression was significantly greater in sheared cells than static controls only at 60 and $120 \mathrm{~min}$ (fig. 4b), suggesting that phosphorylation of JNK in response to FSS lagged behind that of ERK. 
Fig. 3. FSS induces ERK phosphorylation. a Protein lysates of IMCD3 cells exposed to shear or maintained under static conditions were immunoblotted with antipERK and anti-total ERK antibodies. Sheared cells expressed abundant pERK at all time points while cells maintained under static conditions did not. b Densitometric ratios of pERK to total ERK were measured in sheared and unsheared IMCD 3 cells at 10, 30, 60, and $120 \mathrm{~min}$. Sheared cells express significantly more pERK than static control cells $\left({ }^{*} \mathrm{p}<0.05\right.$ compared to static control).

Fig. 4. FSS induces JNK phosphorylation. a Protein lysates of IMCD3 cells exposed to shear or maintained under static conditions were immunoblotted with anti-pJNK and anti-total JNK antibodies. Sheared cells expressed pJNK at 30, 60, and 120 min while cells maintained under static conditions did not. b Densitometric ratios of pJNK to total JNK were measured in sheared and unsheared IMCD3 cells at 10, 30,60 , and $120 \mathrm{~min}$. Sheared cells express significantly more pJNK than static control cells only at 60 and $120 \mathrm{~min}\left({ }^{*} \mathrm{p}<\right.$ 0.05).
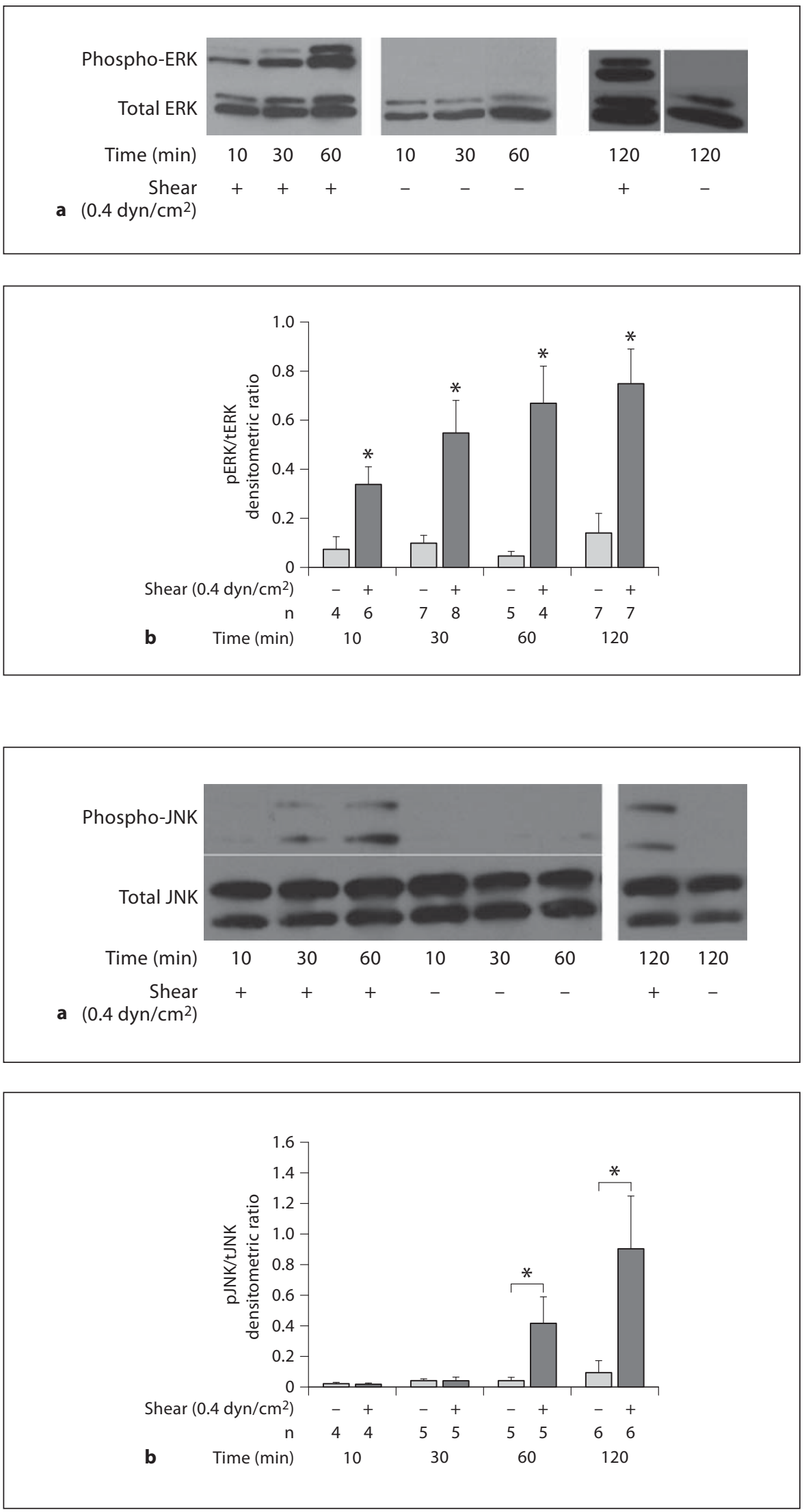

Nephron Physiol 2011;117:p27-p36 


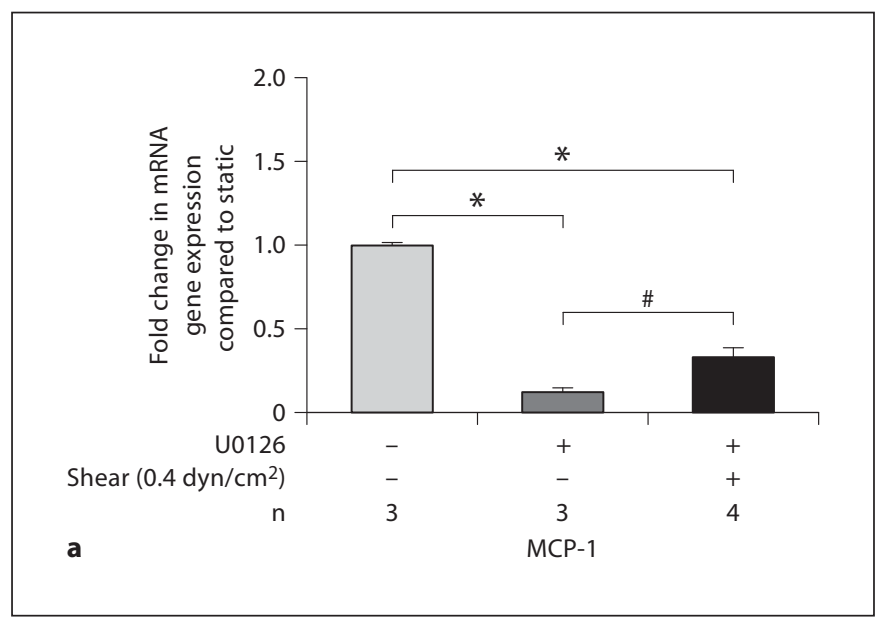

Fig. 5. MAP kinase inhibition reduces FSS-induced MCP-1 expression in wild-type IMCD3 cells. a IMCD3 cells were exposed to $10 \mu \mathrm{M}$ U0126 under static and shear $\left(0.4 \mathrm{dyn} / \mathrm{cm}^{2}\right)$ conditions, and MCP-1 mRNA was expressed as fold change compared to untreated static control. U0126 significantly reduced MCP-1 mRNA expression in static compared to untreated static cells and abolished the shear-induced increase in MCP-1 ( ${ }^{*} \mathrm{p}<0.05$ compared to untreated static cells). U0126-treated sheared cells expressed greater quantities of MCP-1 mRNA than U0126-treated static

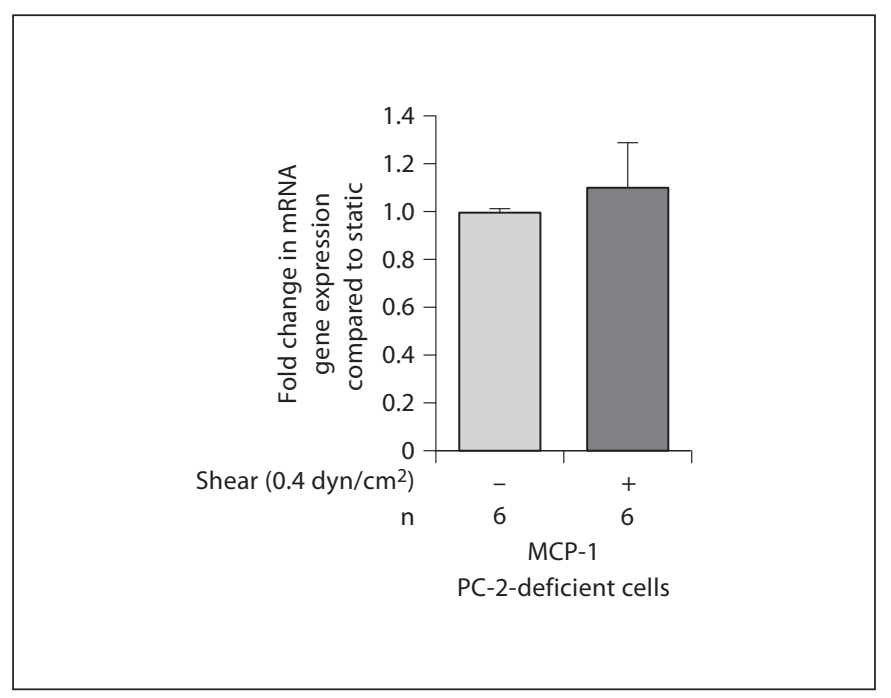

Fig. 6. FSS-mediated MCP-1 mRNA expression is abrogated in PC-2-deficient cells. PC-2-deficient IMCD3 cells were exposed to $0.4 \mathrm{dyn} / \mathrm{cm}^{2}$ of FSS $(\mathrm{n}=6)$ or maintained under static $(\mathrm{n}=6)$ conditions for $2 \mathrm{~h}$, and MCP-1 mRNA expression measured and compared between each treatment group. As opposed to parental IMCD3 cells, FSS did not induce MCP-1 mRNA in PC-2-deficient cells.

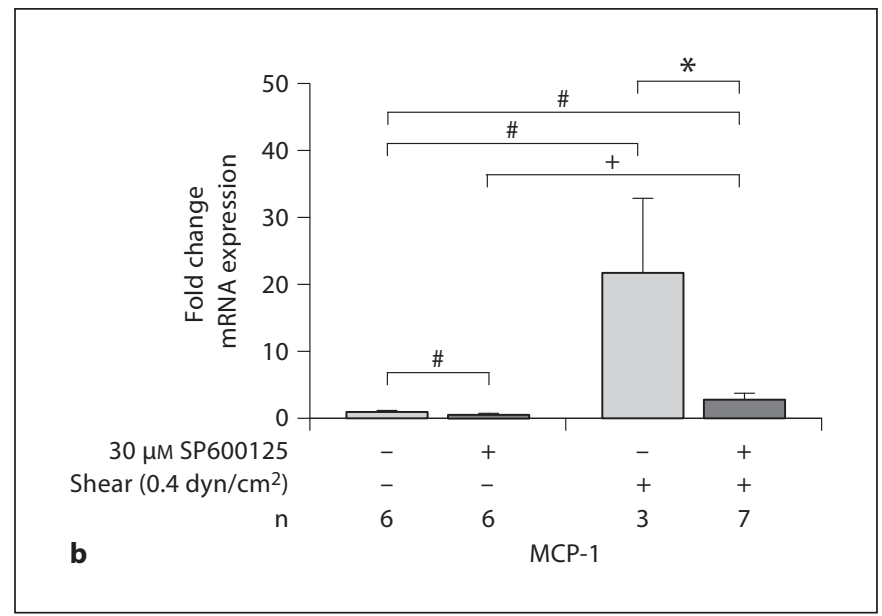

controls ( $\left.{ }^{*} \mathrm{p}<0.05\right)$. b SP600125 $(30 \mu \mathrm{M})$ treatment of static cells reduced expression of MCP-1 mRNA by $45 \%$, but did not prevent the shear-induced increase in expression of MCP-1 ( ${ }^{\#} \mathrm{p}<0.05$ compared to static control). SP600125 did reduce MCP-1 mRNA expression compared to untreated sheared cells $\left({ }^{*} \mathrm{p}<0.05\right)$, while SP600125-treated cells exposed to shear increased MCP-1 mRNA expression compared to SP600125-treated static cells $\left({ }^{+} \mathrm{p}<0.05\right)$.

To evaluate the role of MAP kinase activation in FSSinduced MCP-1 mRNA expression, static and sheared cells were exposed to inhibitors of ERK and JNK pathways, independently, and MCP-1 mRNA expression assayed by qRT-PCR. Inhibition of the pERK pathway by U0126 (10 $\mu \mathrm{M})$ significantly reduced baseline MCP-1 mRNA, and, more importantly, prevented the FSS-induced expression of MCP-1 mRNA (fig. 5a; ${ }^{*} \mathrm{p}<0.05$ compared to static control). Of interest, MCP-1 expression increased in sheared cells treated with ERK inhibitor compared to similarly treated static cells ( ${ }^{\#} \mathrm{p}<0.05$ compared to ERK inhibitor-treated static cells), suggesting that non-ERK-dependent, FSS-activated pathways contribute to this relatively smaller increase in MCP-1. Inhibition of JNK with SP600125 (30 $\mu \mathrm{M})$ suppressed MCP-1 mRNA expression under static conditions by $45 \%$, but FSS induced significant increases in MCP-1 mRNA expression in sheared cells, both in the absence and presence of JNK inhibitor, by $\sim 22$ - and $\sim 3$-fold, respectively (fig. 5b; $\mathrm{p}<0.05$ compared to static control). When comparing MCP-1 mRNA expression of sheared cells in the absence and presence of JNK inhibitor, we find that JNK inhibition reduced MCP-1 mRNA expression compared to shear untreated cells (fig. $5 \mathrm{~b} ;{ }^{*} \mathrm{p}<0.05$ ) suggesting that JNK inhibition only partially prevented FSS-mediated 
Fig. 7. FSS equally induces ERK (a) and JNK (b) in wild-type and PC-2-deficient cells. Parental and PC-2-deficient IMCD3 cells were exposed to FSS at $0.4 \mathrm{dyn} / \mathrm{cm}^{2}$ or maintained under static conditions, and pERK and pJNK expression measured. a IMCD3 $(n=6)$ and PC-2-deficient $(n=6)$ cells increased pERK expression upon exposure to FSS. b Similarly, IMCD3 $(n=3)$ and PC-2-deficient $(n=3)$ cells also equally increase pJNK expression after exposure to FSS.

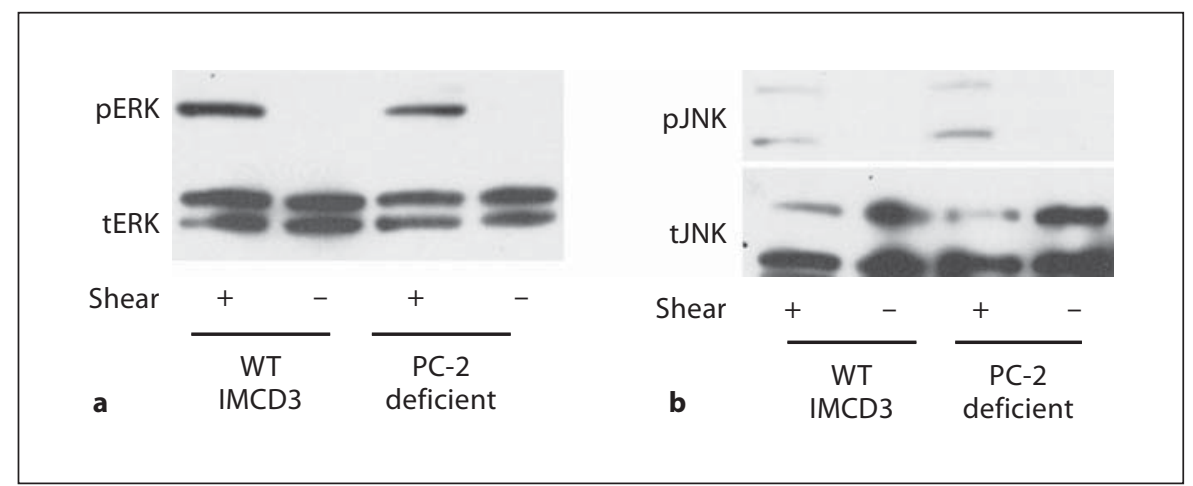

MCP-1 mRNA expression. Moreover, shear-induced MCP-1 expression increased in JNK inhibitor-treated, sheared cells compared to JNK inhibitor-treated, static cells (fig. $5 b ;{ }^{+} \mathrm{p}<0.05$ ) suggesting, as did ERK inhibition, alternative FSS-induced signaling pathways may regulate MCP-1 mRNA expression.

Since PC-2 was shown to be a mechanosensor [9] and a regulator of MAP kinase signaling [30, 31], IMCD3 cells deficient in PC-2 were exposed to FSS to test whether FSS-induced MCP-1 and MAP kinase signaling remained intact. PC-2-deficient cells showed no increase of MCP-1 mRNA expression (fig. 6) after exposure to FSS of an identical level and duration as wild-type IMCD3 cells. Because overexpression of PC-2 activates MAP kinase (JNK and p38, specifically) and downstream AP-1 promoter activity, we suspected that underexpression of PC-2 would inhibit FSS-induced MAP kinase signaling. To test this, IMCD3- and PC-2-deficient cells were exposed to FSS of $0.4 \mathrm{dyn} / \mathrm{cm}^{2}$ to compare FSS-induced pERK and pJNK expression. However, steady-state levels of pERK (fig. 7a; $n($ IMCD3) $=6$ and $n(P C-2)=6)$ and pJNK (fig. 7b; $n($ IMCD3) $=3$ and $n(P C-2)=3$ ) did not differ between FSS-exposed wild-type and PC-2-deficient IMCD3 cells, suggesting that activation of these signaling pathways was unaffected by PC-2 deficiency. In addition, gross cilia morphology did not differ between parental (fig. 8a) and PC-2-deficient (fig. 8b) IMCD3 cells with regard to prevalence of cilia or number of cilia per cell (a single cilium was found on each cell).

In the context of normal FSS-induced ERK and JNK phosphorylation and grossly normal cilia morphology, but absent FSS-induced MCP-1 mRNA in PC-2-deficient cells, we suspected that PC-2-deficient cells were unable to regulate nucleocytoplasmic localization of $\mathrm{pERK}$. To address this possibility, PC-2-deficient and wild-type IMCD3 cells were exposed to FSS as described above, nu- clear and cytosolic proteins extracted and electrophoresed, and protein lysates immunoblotted with antibodies directed against pERK. After detecting for pERK, the blot was stripped and GAPDH expression (a cytosolic marker) assessed to exclude cross-contamination of the cytoplasm into the nuclear fraction. In 3 of 4 experiments conducted on IMCD3 cells, pERK was abundantly observed in the cytosolic and nuclear fractions of wild-type IMCD3 cells (fig. 9) exposed to FSS. However, PC-2-deficient cells exposed to FSS only expressed cytosolic and lacked nuclear pERK (fig. 9) expression in 3 of 3 experiments performed, suggesting PC-2-deficient cells are unable to traffic activated ERK into the nucleus and, thus, unable to induce MCP-1 mRNA expression.

\section{Discussion}

The purpose of this study was twofold: (1) to test whether that FSS induces MAP kinase signaling pathways and gene expression in a collecting duct cell line and (2) to identify proteins that relay these mechanical cues into biological responses. To this end, we showed that FSS induces (1) ERK- and JNK-dependent MCP-1 mRNA expression in collecting duct cells, and that (2) PC-2 is a mediator of FSS-induced nuclear pERK and cellular MCP-1 expression. Flow/shear-induced MAP kinase activation was first described in ECs $[25,26]$, and has also been observed in hepatic epithelial HeLa cells [25], bone marrow stromal cells [38] and osteoblastic cells [39, 40]. However, up to this time, the effect of FSS on MAP kinase signaling and gene expression in renal epithelial cells was unknown. On the other hand, increases in tubular flow rate induce nitric oxide (NO) synthase and NO production in isolated microperfused thick ascending limbs by a PI3-kinase-dependent mechanism [41, 42]. Utilizing a 


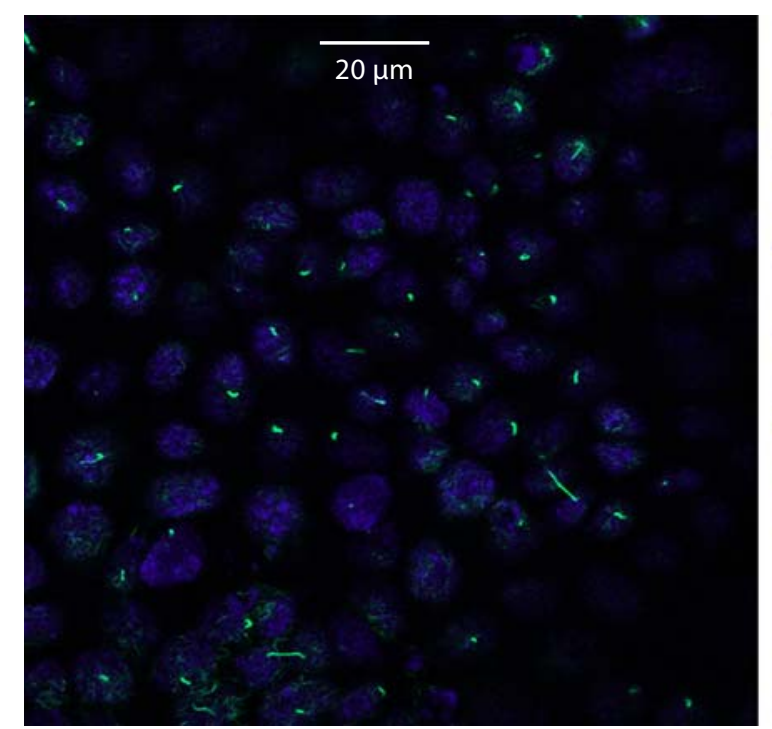

a

WT IMCD3

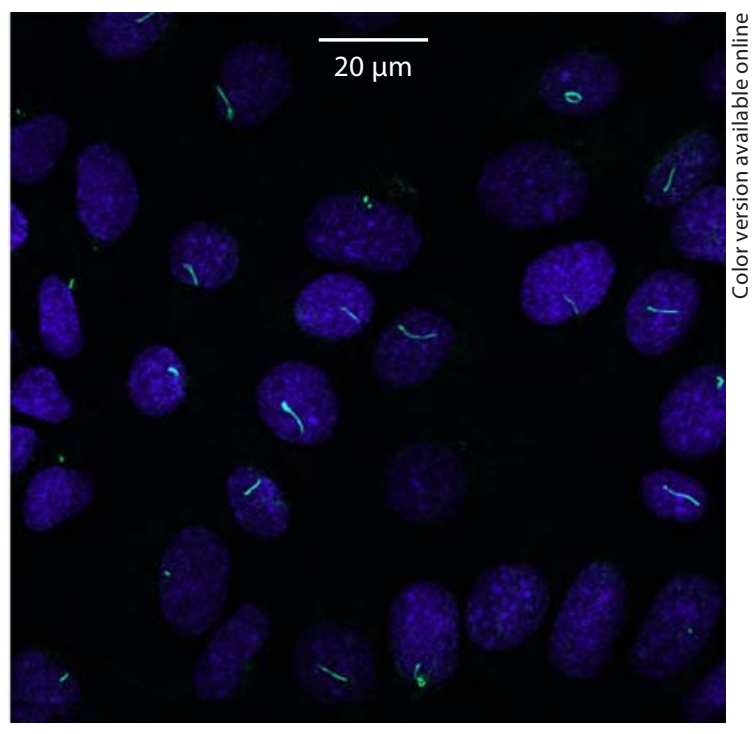

b

PC-2-deficient

Fig. 8. Cilia are expressed in parental and PC-2-deficient IMCD3 cells. Wild-type and PC-2-deficient cells were labeled with a murine monoclonal anti-acetylated- $\alpha$-tubulin antibody (green) to localize cilia in each cell type. IMCD3 (a) and PC-2-deficient (b) cells each expressed a single cilium on the surface of each cell. No gross ciliary aberrations were noted in the PC-2-deficient cells.

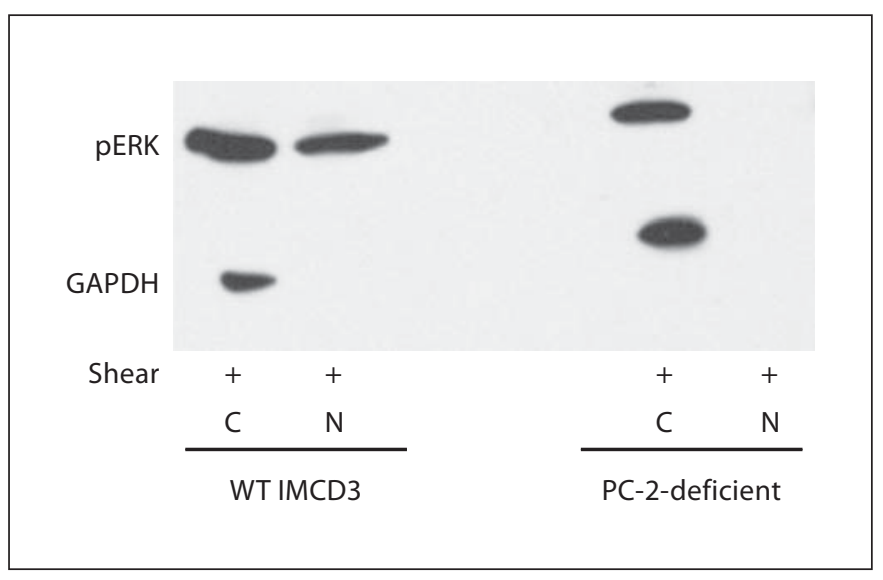

Fig. 9. FSS induces nuclear pERK expression in wild-type IMCD3 cells but not in PC-2-deficient cells. Parental and PC-2-deficient IMCD3 cells were exposed to FSS, nuclear $(\mathrm{N})$ and cytoplasmic (C) fractions isolated, and immunoblotted with an anti-phospho-ERK antibody. FSS-induced nuclear expression of pERK in IMCD3 cells (in 3 of 4 experiments), but did increase nuclear pERK in PC-2-deficient cells (in 3 of 3 experiments). GAPDH, a cytoplasmic marker, demonstrates there is no cross-contamination of cytoplasmic fraction into nuclear fraction. proximal tubule cell culture model, Essig et al. [43] were the first to demonstrate that apical FSS reduces urokinase and t-PA mRNA and enzymatic activity which, they hypothesized, led to reduced turnover of tubulointerstitium and, thus, renal interstitial fibrosis. Finally, most recently, FSS-induced PKC-dependent phosphorylation and nuclear export of histone deacetylase-5 (HDAC5) in mouse embryonic kidney (MEK) cells which was inhibited after reducing PC-1 protein expression in MEK cells [44]. Our data on FSS-induced MAP kinase activation add to the burgeoning literature suggesting that biomechanical forces activate a specific repertoire of downstream signaling proteins in renal tubular epithelial cells.

Our next and more interesting finding was that reduction of PC-2 protein expression to $\sim 20 \%$ of normal inhibited flow/shear-induced MCP-1 expression by preventing FSS-induced nuclear pERK expression. Because activation of ERK is primarily at the plasma membrane or at other endomembranes [45], nuclear localization of pERK requires translocation across the nuclear envelope. Thus, we speculate that absence FSS-induced nuclear pERK expression reflects a defect in pERK translocation across the nuclear membrane. This finding actually runs counter to the observations of Grimm et al. [31] who showed that reduced PC-2 expression was associated with in- 
creased ligand (i.e. EGF or HGF)-dependent localization of pERK. This difference, we speculate, likely reflects the alternative stimuli, FSS versus receptor ligand binding, in our studies versus their studies. Moreover, Grimm et al. [31] utilized immunofluorescence microscopy to localize pERK in the nucleus and cy toplasm after EGF/HGF treatment while our studies isolated nuclear and cytoplasmic fractions and measured pERK expression by immunoblotting after FSS. The mechanism by which PC-2 regulates nuclear cytoplasmic localization is unknown; however, $\left[\mathrm{Ca}^{2+}\right]_{\mathrm{i}}$ likely contributes to the proportion of pERK in cytosol and nucleus [46, 47]. Overexpression of the D511V PC-2 mutant, in which a single mutation in the third transmembrane domain abrogates cation channel activity, also induced EGF/HGF-dependent pERK nuclear localization, suggesting cation channel activity was necessary to maintain cytosolic expression (or prevent nuclear expression) of pERK [31]. Studies are ongoing to evaluate the contribution of FSS-induced changes in $\left[\mathrm{Ca}^{2+}\right]_{\mathrm{i}}$ on pERK localization, as well as the differences in FSS-induced $\left[\mathrm{Ca}^{2+}\right]_{\mathrm{i}}$ in wild-type and PC-2-deficient IMCD 3 cells.

In sum, FSS induces renal epithelial MAP kinase signaling, whose spatial localization is regulated by cellular PC-2 expression. The importance of this novel finding is not entirely clear; however, we speculate that FSS is an important component of normal tubular development, as Vasilyev et al. [15] elegantly demonstrated. In the setting of PC-2 deficiency, FSS may not appropriately localize activated MAP kinases to their subcellular compartments in tubular epithelial cells. Since MAP kinases are known to regulate cellular migration $[48,49]$, altering the flowinduced MAP kinase localization in PC-2-deficient cells may contribute to dysregulated epithelial migration and hence cyst formation. Thus, further studies are needed to understand how these basic physiologic abnormalities contribute the renal cystic phenotype.

\section{Acknowledgements}

We gratefully acknowledge the technical assistance of Beth Zavilowitz and the helpful suggestions of Dr. Lisa Satlin in the preparation of the manuscript. This data was presented, in part, as a poster presentation at the 2008 American Society of Nephrology Meeting in Philadelphia, Pa. This work was supported by KO8 DK062172 (R.R.), PKD Foundation Standard Grant (R.R.), and Norman S. Coplon Award (R.R.) from Satellite Healthcare. Confocal laser scanning microscopy was performed at the MSSM-Microscopy Shared Resource Facility, supported with funding from NIH-NCI shared resources grant (5R24 CA095823-04), NSF Major Research Instrumentation grant (DBI-9724504) and NIH shared instrumentation grant (1 S10 RR0 9145-01).

\section{References}

1 Li YS, Haga JH, Chien S: Molecular basis of the effects of shear stress on vascular endothelial cells. J Biomech 2005;38:1949-1971.

$\checkmark 2$ Nauli SM, Kawanabe Y, Kaminski JJ, Pearce WJ, Ingber DE, Zhou J: Endothelial cilia are fluid shear sensors that regulate calcium signaling and nitric oxide production through polycystin-1. Circulation 2008;117:1161-1171.

3 AbouAlaiwi WA, Takahashi M, Mell BR, Jones TJ, Ratnam S, Kolb RJ, Nauli SM: Ciliary polycystin- 2 is a mechanosensitive calcium channel involved in nitric oxide signaling cascades. Circ Res 2009;104:860-869.

4 Duan Y, Gotoh N, Yan Q, Du Z, Weinstein AM, Wang T, Weinbaum S: Shear-induced reorganization of renal proximal tubule cell actin cytoskeleton and apical junctional complexes. Proc Natl Acad Sci USA 2008; 105:11418-11423.

5 Satlin LM, Carattino MD, Liu W, Kleyman TR: Regulation of cation transport in the distal nephron by mechanical forces. Am J Physiol Renal Physiol 2006;291:F923-F931.

6 Shibazaki S, Yu Z, Nishio S, Tian X, Thomson RB, Mitobe M, Louvi A, Velazquez $\mathrm{H}$, Ishibe S, Cantley LG, Igarashi P, Somlo S:
Cyst formation and activation of the extracellular regulated kinase pathway after kidney specific inactivation of PKD1. Hum Mol Genet 2008.

7 Praetorius HA, Spring KR: Bending the MDCK cell primary cilium increases intracellular calcium. J Membr Biol 2001;184:7179 .

8 Praetorius HA, Spring KR: Removal of the MDCK cell primary cilium abolishes flow sensing. J Membr Biol 2003;191:69-76.

-9 Nauli SM, Alenghat FJ, Luo Y, Williams E, Vassilev P, Li X, Elia AE, Lu W, Brown EM, Quinn SJ, Ingber DE, Zhou J: Polycystins 1 and 2 mediate mechanosensation in the primary cilium of kidney cells. Nat Genet 2003; 33:129-137.

10 Siroky BJ, Ferguson WB, Fuson AL, Xie Y, Fintha A, Komlosi P, Yoder BK, Schwiebert EM, Guay-Woodford LM, Bell PD: Loss of primary cilia results in deregulated and unabated apical calcium entry in ARPKD collecting duct cells. Am J Physiol Renal Physiol 2006;290:F1320-F1328

11 Rohatgi R, Battini L, Kim P, Israeli S, Wilson PD, Gusella GL, Satlin LM: Mechanoregula- tion of intracellular $\mathrm{Ca}^{2+}$ in human autosomal recessive polycystic kidney disease cystlining renal epithelial cells. Am J Physiol Renal Physiol 2008;294:F890-F899.

12 Masyuk AI, Masyuk TV, Splinter PL, Huang BQ, Stroope AJ, LaRusso NF: Cholangiocyte cilia detect changes in luminal fluid flow and transmit them into intracellular $\mathrm{Ca}^{2+}$ and cAMP signaling. Gastroenterology 2006; 131:911-920

-13 Xu C, Shmukler BE, Nishimura K, Kaczmarek E, Rossetti S, Harris PC, WandingerNess A, Bacallao RL, Alper SL: Attenuated, flow-induced ATP release contributes to absence of flow-sensitive, purinergic $\mathrm{Ca}^{2+}$ signaling in human ADPKD cyst epithelial cells. Am J Physiol Renal Physiol 2009; 296:F1464-F1476.

$14 \mathrm{Xu}$ C, Rossetti S, Jiang L, Harris PC, BrownGlaberman U, Wandinger-Ness A, Bacallao RL, Alper SL: Human ADPKD primary cyst epithelial cells with a novel, single codon deletion in the PKD1 gene exhibit defective ciliary polycystin localization and loss of flowinduced $\mathrm{Ca}^{2+}$ signaling. Am J Physiol Renal Physiol 2007;292:F930-F945. 
15 Vasilyev A, Liu Y, Mudumana S, Mangos S, Lam PY, Majumdar A, Zhao J, Poon KL, Kondrychyn I, Korzh V, Drummond IA: Collective cell migration drives morphogenesis of the kidney nephron. PLoS Biol 2009; 7:e9.

16 McGrath J, Somlo S, Makova S, Tian X, Brueckner M: Two populations of node monocilia initiate left-right asymmetry in the mouse. Cell 2003;114:61-73.

17 Schena FP, Gesualdo L: Pathogenetic mechanisms of diabetic nephropathy. J Am Soc Nephrol 2005;16(suppl 1):S30-S33.

18 Hostetter TH, Olson JL, Rennke HG, Venkatachalam MA, Brenner BM: Hyperfiltration in remnant nephrons: a potentially adverse response to renal ablation. Am J Physiol 1981;241:F85-F93.

19 Pennell JP, Bourgoignie JJ: Adaptive changes of juxtamedullary glomerular filtration in the remnant kidney. Pflugers Arch 1981;389: 131-135.

20 Rohatgi R: Clinical manifestations of hereditary cystic kidney disease. Front Biosci 2008;13:4175-4197.

-21 Martinez-Maldonado M, Yium JJ, Eknoyan G, Suki WN: Adult polycystic kidney disease: studies of the defect in urine concentration. Kidney Int 1972;2:107-113.

-22 Gabow PA, Kaehny WD, Johnson AM, Duley IT, Manco-Johnson M, Lezotte DC, Schrier RW: The clinical utility of renal concentrating capacity in polycystic kidney disease. Kidney Int 1989;35:675-680.

-23 Gagnadoux MF, Habib R, Levy M, Brunelle F, Broyer M: Cystic renal diseases in children. Adv Nephrol Necker Hosp 1989; 18:3357.

24 Hebert LA, Greene T, Levey A, Falkenhain ME, Klahr S: High urine volume and low urine osmolality are risk factors for faster progression of renal disease. Am J Kidney Dis 2003;41:962-971.

-25 Shyy JY, Lin MC, Han J, Lu Y, Petrime M, Chien S: The cis-acting phorbol ester 12-Otetradecanoylphorbol 13-acetate-responsive element is involved in shear stress-induced monocyte chemotactic protein-1 gene expression. Proc Natl Acad Sci USA 1995;92: 8069-8073.

26 Shyy YJ, Hsieh HJ, Usami S, Chien S: Fluid shear stress induces a biphasic response of human monocyte chemotactic protein-1 gene expression in vascular endothelium. Proc Natl Acad Sci USA 1994;91:4678-4682.
27 Jo H, Sipos K, Go Y-M, Law R, Rong J, McDonald JM: Differential effect of shear stress on extracellular signal-regulated kinase and $\mathrm{N}$-terminal Jun kinase in endothelial cells. Gi2- and $G \beta / \gamma$-dependent signaling pathways. J Biol Chem 1997;272:1395-1401.

28 Ishida T, Peterson TE, Kovach NL, Berk BC: MAP kinase activation by flow in endothelial cells. Role of $\beta_{1}$-integrins and tyrosine kinases. Circ Res 1996;79:310-316.

29 Li S, Kim M, Hu YL, Jalali S, Schlaepfer DD, Hunter T, Chien S, Shyy JY: Fluid shear stress activation of focal adhesion kinase. Linking to mitogen-activated protein kinases. J Biol Chem 1997;272:30455-30462.

-30 Arnould T, Sellin L, Benzing T, Tsiokas L, Cohen HT, Kim E, Walz G: Cellular activation triggered by the autosomal dominant polycystic kidney disease gene product PKD2. Mol Cell Biol 1999;19:3423-3434.

31 Grimm DH, Karihaloo A, Cai Y, Somlo S, Cantley LG, Caplan MJ: Polycystin-2 regulates proliferation and branching morphogenesis in kidney epithelial cells. J Biol Chem 2006;281:137-144

32 Battini L, Macip S, Fedorova E, Dikman S, Somlo S, Montagna C, Gusella GL: Loss of polycystin-1 causes centrosome amplification and genomic instability. Hum Mol Genet 2008; 17:2819-2833.

33 Battini L, Fedorova E, Macip S, Li X, Wilson PD, Gusella GL: Stable knockdown of polycystin-1 confers integrin- $\alpha_{2} \beta_{1}$-mediated anoikis resistance. J Am Soc Nephrol 2006; 17:3049-3058.

- 34 Woda CB, Miyawaki N, Ramalakshmi S, Ramkumar M, Rojas R, Zavilowitz B, Kleyman TR, Satlin LM: Ontogeny of flow-stimulated potassium secretion in rabbit cortical collecting duct: functional and molecular aspects. Am J Physiol Renal Physiol 2003; 285:F629-F639.

35 Najjar F, Zhou H, Morimoto T, Bruns JB, Li HS, Liu W, Kleyman TR, Satlin LM: Dietary $\mathrm{K}^{+}$regulates apical membrane expression of maxi-K channels in rabbit cortical collecting duct. Am J Physiol Renal Physiol 2005; 289:F922-F932.

-36 Bennett BL, Sasaki DT, Murray BW, O’Leary EC, Sakata ST, Xu W, Leisten JC, Motiwala A, Pierce S, Satoh Y, Bhagwat SS, Manning AM, Anderson DW: SP600125, an anthrapyrazolone inhibitor of Jun N-terminal kinase. Proc Natl Acad Sci USA 2001;98: 13681-13686.

- 37 Liu W, Xu S, Woda C, Kim P, Weinbaum S, Satlin LM: Effect of flow and stretch on the $\left[\mathrm{Ca}^{2+}\right]_{\mathrm{i}}$ response of principal and intercalated cells in cortical collecting duct. Am J Physiol Renal Physiol 2003;285:F998-F1012.
38 Grellier M, Bareille R, Bourget C, Amedee J: Responsiveness of human bone marrow stromal cells to shear stress. J Tissue Eng Regen Med 2009;3:302-309.

- 39 Young SR, Gerard-O’Riley R, Kim JB, Pavalko FM: Focal adhesion kinase is important for fluid shear stress-induced mechanotransduction in osteoblasts. J Bone Miner Res 2009;24:411-424.

-40 Liu D, Genetos DC, Shao Y, Geist DJ, Li J, Ke HZ, Turner CH, Duncan RL: Activation of extracellular-signal regulated kinase (ERK1/2) by fluid shear is $\mathrm{Ca}^{2+}$ - and ATPdependent in MC3T3-E1 osteoblasts. Bone 2008;42:644-652.

41 Ortiz PA, Hong NJ, Garvin JL: Luminal flow induces eNOS activation and translocation in the rat thick ascending limb. Am J Physiol Renal Physiol 2004;287:F274-F280.

42 Ortiz PA, Hong NJ, Garvin JL: Luminal flow induces eNOS activation and translocation in the rat thick ascending limb. II. Role of PI3-kinase and Hsp90. Am J Physiol Renal Physiol 2004;287:F281-F288.

-43 Essig M, Terzi F, Burtin M, Friedlander G: Mechanical strains induced by tubular flow affect the phenotype of proximal tubular cells. Am J Physiol Renal Physiol 2001; 281:F751-F762.

44 Xia S, Li X, Johnson T, Seidel C, Wallace DP, Li R: Polycystin-dependent fluid flow sensing targets histone deacetylase-5 to prevent the development of renal cysts. Development 2010;137:1075-1084.

45 Ramos JW: The regulation of extracellular signal-regulated kinase in mammalian cells. Int J Biochem Cell Biol 2008:40:2707-2719.

- 46 Chuderland D, Marmor G, Shainskaya A, Seger R: Calcium-mediated interactions regulate the subcellular localization of extracellular signal-regulated kinases. J Biol Chem 2008:283:11176-11188

47 Chuderland D, Seger R: Calcium regulates ERK signaling by modulating its proteinprotein interactions. Commun Integr Biol 2008;1:4-5.

-48 Wu WS, Wu JR, Hu CT: Signal cross talks for sustained MAPK activation and cell migration: the potential role of reactive oxygen species. Cancer Metastasis Rev 2008;27:303-314.

49 Ishibe S, Joly D, Liu ZX, Cantley LG: Paxillin serves as an ERK-regulated scaffold for coordinating FAK and Rac activation in epithelial morphogenesis. Mol Cell 2004;16:257267. 